\title{
AVANÇANDO NA CONSTRUÇÃO DE UMA REVISTA PLURAL, POPULAR E DE QUALIDADE
}

\author{
Marcelo Pires Dias ${ }^{1}$, Gustavo Goulart Moura ${ }^{1}$
}

É com grande entusiasmo que temos a oportunidade lançar o volume 6, n 3, da Revista Ethnoescientia, periódico ligado à Sociedade Brasileira de Etnobiologia e Etnoecologia (SBEE). Como havíamos pontuado no primeiro número lançado no início desse ano, a revista Ethnoscientia passaria por importantes mudanças, sendo a primeira delas a sua mudança de local de hospedagem, que agora passa a integrar o rol de revistas do Portal de Periódicos da Universidade Federal do Pará, a maior universidade da Pan-Amazônia. Esse processo envolveu a migração de todas as edições, cadastro de avaliadores e editores, além da atribuição de um novo prefixo editorial. Infelizmente, não foi possível aproveitar o banco de dados de leitores do site antigo, gerando a perda de aproximadamente seis mil cadastrados. Uma lástima!

Avançamos, também, na indexação da revista e na divulgação científica. Hoje, estamos indexados em sete plataformas, sendo três nacionais e quatro internacionais, e continuaremos ampliando as indexações neste segundo semestre. Na divulgação científica, ampliamos a atuação nas redes sociais da internet, aumentamos o número de seguidores no Facebook (hoje somos quase 2150 seguidores) e passamos a operar no Instagram, com a criação de conteúdos específicos sobre a revista nas seções de divulgação: "vem aí!", "vem ver/ler!", "se liga!" e "lançamento de artigos no feed". Além delas, já estamos trabalhando no lançamento de mais duas: "tu sabias?" e "agradecimentos". No início de 2022, esperamos estrear um canal próprio no YouTube para realizar debates sobre temáticas importantes e entrevistas com autores de dossiês e artigos que se destacarem por sua relevância e qualidade em cada um de nossos números ordinários e especiais.

Ainda no campo da divulgação científica, estamos apoiando a publicidade da II Jornada de Etnodiversidade, organizada por uma das maiores faculdades de educação diferenciada do país, a Faculdade de Etnodiversidade (FACETNO/UFPA). A FACETNO possui em torno de 300 discentes oriundos exclusivamente de povos indígenas, quilombolas, comunidades tradicionais e campesinos de todo o estado do Pará. O evento conta com aproximadamente 300 ouvintes e 67 trabalhos inscritos de todas as 
regiões do Brasil. No início do ano de 2022, será publicado um dossiê a partir de trabalhos selecionados neste mesmo evento, transformando o apoio à divulgação científica em um trabalho de cooperação na publicação científica de qualidade. A expectativa é que esse dossiê produza avanços nas etnociências, alçando as pautas de (etno)educação e (etno)desenvolvimento a um lugar central de debates políticos e de produção (inter)científica engajada, feitos também por povos indígenas, quilombolas, comunidades tradicionais e campesinos que têm acessado o ensino superior nas últimas duas décadas em todo o país, em boa medida como resultado de políticas afirmativas.

O primeiro artigo dessa edição, intitulado "Plantas medicinais utilizadas em rituais de umbanda: estudo de caso no Sul do Brasil", cuja autoria é de Maria Eduarda Alves Ferreira, Guilherme Alves Elias, Viviane Kraiseki Assunção e Vanilde Citadini-Zanette, inaugura o novo layout com fontes tipográficas e disposição do texto cuidadosamente pensadas para tornar mais amigável a leitura dos artigos em dispositivos de leitura digital (celulares, tablets, notebooks e desktops), opção feita pela revista desde sua fundação. Associado a esse novo layout, estamos criando uma nova identidade visual para toda a revista que estará relacionada com a sua essência, escopo e com a identidade que já vem sendo construída em nossas redes sociais.

Ademais, não perdemos de vista aquela que consideramos nossa meta mais importante: avançar na qualidade da revista (Qualis, fator de impacto etc.) avaliada pelas instituições responsáveis. Para este empreendimento, esperamos continuar contando com os/as nossos/as autores/as maravilhosos/as para o envio de seus artigos e iremos fazer um planejamento estratégico ainda neste segundo semestre.

Tais avanços são resultado do contínuo processo de profissionalização que a revista tem passado desde a sua fundação. Além do conselho editorial e dos pareceristas, atualmente somos uma equipe multidisciplinar de 25 profissionais trabalhando incansavelmente nas funções de gestão, editoração e divulgação científica, ainda que com condições adversas criadas pelo contexto de genocídio em que o país vive. A todos esses profissionais, os editores-chefes agradecem imensamente a disposição, o empenho e o profissionalismo com que tem trabalhado e por estarem conosco na trincheira da r-existência aos ataques distópicos às instituições democráticas do país, inclusive as ligadas à produção científica. A todos os brasileiros/as, a equipe desta revista se solidariza pela perda de colegas, amigos, familiares e pessoas queridas que somam a deprimente, inacreditável e inaceitável marca de 500 mil vidas ceifadas, em sua maior parte de morte matada. Estamos em luto!

Altamira, 20 de junho de 2021. 